\title{
THE SOCIOECONOMIC CONSEQUENCES OF INDUSTRIAL DEVELOPMENT
}

\author{
Jan Mertl, Radim Valenčík
}

\begin{abstract}
Current rapid structural changes in economy have huge consequences for the socioeconomic environment as a whole. The article analyses these changes at macroeconomic level and their relationship to industry, employment, social systems behaviour and performance of businesses connected with human capital development, but also to the (microeconomic) position of individual subjects. The solutions that are rooted in the acquisition, maintaining and utilizing of human capital will be discussed. We will discuss new incentives for social investment and providing productive services, identify barriers of economic growth in current socioeconomic system and show selected obstacles that prevent productive utilization of human capital. Although these issues are controversial by nature, have deep systemic causes and they cannot be resolved immediately or by simple measures, we take a scientific effort to search for opportunities that support adaptive processes, utilize the human potential that is available and can be improved further when decreasing our dependency on material conditions of existence.
\end{abstract}

\section{Keywords}

industrial development, productive employment, social investment, economic growth

\section{Introduction}

Recently, we can observe in developed countries significant changes in the character of industry, employment and social systems. Their evaluation highly depends on the point of view that the evaluators take into account. Of course, when considering productivity and reliability of manufacturing process, the innovations are highly welcomed, however their real usage and adaptation to their effects is not a simple and spontaneous process.

We can understand the concept of so-called Fourth Industrial Revolution also as an expression of the inertial thinking in the historical turning point. Its consequences contain calculations that $40 \%$ or even more people could be (on the labour market) unnecessary. In addition, once the system begins to exhibit the economic and social consequences of the current economic system and loses its effectiveness, not being able to open up new growth areas, the concept of Fourth Industrial Revolution could be hijacked to social segregation and market discrimination.

Those changes are challenging the traditional social policy approaches similarly to the industrial revolution did it in nineteenth century, when tough issues had arisen and led to introduction of many new socioeconomic measures, such as compulsory education, social insurance schemes, labour law, universal availability of health care, fiscal and monetary policy and so on. Therefore, it is not just by chance that today's changes influence those areas too. 


\section{Theoretical background and methodological approach}

In this article, we use the definition of the problem using the concept of "intensity of use of investment opportunities" in relation to human and social capital (Bourdieu, 1986; Valenčík, $2014,2015)$. We are extending our thinking horizon in the direction of the path to the economy, which can be of the "produce nearly anything from almost nothing" character and consequently to possible extension to the existing type of civilization. We show how a new type of growth associated with the general nature of labour and the mechanisms of the economy of productive consumption. The aim of the article is thus, within the above framework, perform a critical analysis of the concept, which is referred to as the vision of the Fourth Industrial Revolution, to put it into a broader socioeconomic context and show some limits of their usual understanding, including an effort to positive reinterpretation of their often problematic consequences presented.

Actually, we can hypothesize that on the background of the concept of the Fourth Industrial Revolution fundamental social changes are underway consisting in a transition to an economy based on productive services, i.e. the services making the dynamics of economic growth by enabling the acquisition, preservation and utilization of human capital. Afterwards they can significantly increase the intensity and character of innovation. Thus, we also want to show that besides the necessity of demanding adaptation processes it also provides significant development opportunities for broad participation in productive activities in areas such as the implementation and usage of modern technologies (Kůs, 2015) and productive services delivery (Valenčík, 2015). Productive services (Valenčík, 2014) are significantly bound to national and regional economy. In addition, in a certain sense, it is true that those services provision and consumption are closely related to social insurance and other pension schemes performance and regional development (Hujo, 2014). It is not just about the various forms of postgraduate education and health care, but also e.g. spa service and a range of advanced social services (Vostatek, et al, 2013). Tackling extension of the term of productive use and thus stimulate effective demand (Čadil, 2010), which is linked to the consumption of health, education and other nationally and regionally specific services, which are highly useful to maintain and renew individual human capabilities.

From a theoretical point of view, we can see it as the fifth major change in the evolution of human civilization. The sequence of first four was from collecting to hunting, from hunting to shepherding, from shepherding to agriculture, from agriculture to industry. Now the fifth one is from industry to the economy of productive services (which is based on education, health care, culture, leisure services, and that all related to significant dynamic changes made possible by human knowledge).

The condition of these changes is to improve the market mechanism so that it is capable of much better and broader investments related to the acquisition, preservation and utilization of human capital. Another requirement is to create equal opportunities (chances), which means overcoming the long-term effects of various aspects of the current economic and social segregation, exclusion and closing various groups from the main direction of social development and even turning against the natural direction of social development.

These problems of adapting to the changes in the production process and the involvement of production factors have long tradition in socioeconomic analyses since the times of Marx (1974) and within innovative approaches of R. Richta (1966), which were at its time ahead of current concepts like the Fourth Industrial Revolution. They are also covered in economics of welfare and happiness (Klusoň, 2005; Mlčoch, 2007), social policy approaches (Krebs, 2015) and the theories of productive utilization of human capabilities and current reflection in this area (Valenčík, 2014, 2015). Because of the size of the article is limited, we refer only here at theoretical background also to the problem income and wealth differentiation, which in parallel with the rise of the Fourth Industrial Revolution is accelerating and is currently already clearly demonstrated statistically (Credit Suisse, 2015; IMF, 2015). 


\section{Results}

The economic growth may be substantially simultaneously dynamic and sustainable. It even has to be considerably dynamic to be sustainable, of course given its real character changes accordingly.

The sustainability of growth is due to a significant increase in the intensity of innovation processes, and it is based on a fuller use of the investment opportunities, which a man possesses. Productive services (e.g. health care, education, culture, leisure services) play in increasing dynamics of economic growth while protecting its sustainability this dual role:

- First, they are themselves part of the economic growth (including how it is expressed in terms of GDP indicator).

- Second, by acting on the use of investment opportunities associated with the development of human capabilities (acquisition, preservation and utilization of human capital), allow to increase the useful effects for virtually all products while significantly lowering their costs of production (including costs in their expression through natural units).

If we understand the duality of targeting of the economic processes as meeting the experiential richness of the human life while increasing human productive capacities, which are becoming the most dynamic factor of growth, while they imprint economic growth a new quality (the higher level of fulfilment of human happiness), then we can postulate that to every natural restrictions of fulfilling this target such a sum of innovations exists, that can achieve such a target, despite the default restrictions posed by nature. The possibility to realize the innovation is then conditional on the use of investment opportunities associated with the development of human capabilities. In the event that the economic system develops inertia, i.e. if for the use of investment opportunities associated with the development of proinnovative-oriented human capabilities are in the economic system not created conditions, then the opportunities for economic growth face natural and consequently various social barriers. This will in turn be reflected in the form of various crisis phenomena and conflicts. Current recurrences of financial crises have their origins in the fact that the inertial continuation of economic growth in its current form, with low consumption effects on the development of pro-innovative-oriented human capabilities, crashed to inherent limitations. Traditional methods of demand stimulation of economic growth are losing effectiveness in these conditions.

The decisive condition for the transition to an economy of productive services is the involvement of entities operating in the area of productive services associated with the acquisition, preservation and utilization of human capital, creating a feedback loop between the effects of productive services and the financing of these entities can contribute substantially to the higher dynamics of economic growth, positively change his the character and people's quality of life. Only the creation of these feedbacks (in the form of improving market mechanisms) allows you to create a competitive environment in which they created enough pressure to substantially increase innovative activities focused on the acquisition, preservation and utilization of human capital - and thus the gradual gaining of equal opportunities in terms of their independence from the original wealth position.

The world that we live in (what is nature and what constitutes nature) has a potential to allow the creation of nearly anything from almost nothing. 
The type of economy can be born that much more fully exploits investment opportunities in the acquisition, preservation and utilization of human capital, and which would characterizes much higher intensity of innovation processes. This can in next two hundred years lead, because of rapidly growing innovative potential of the society, to socioeconomic system being to the vast extent "relieved" (liberated) from the material conditions of its existence, i.e. from strict dependence on sources of raw materials and energy. Everything a man would need for a much richer life than that now can be produced with a lower burden of our natural environment. Moreover, even for a substantially higher population counts.

If someone is in doubt about those processes, he can also imagine how many resources today we use just for moving the goods around the planet. Extensive transport and carrying services often make great share of the product costs and price and many raw materials is consumed during extensive transports.

We should note that only a small fraction of people would act professionally as one who today is called the term "scientist", i.e. as someone who professionally "thinks up innovations". The large majority of people can work in productive services.

Once society has solved the historical role of liberation from the material conditions of their existence, will then tackle an even more important role in the liberation from the physical conditions of its existence, i.e. time-space limitations. Nevertheless, we can let this be for distant future generations. The current transition to a society whose economy is based on productive services gives sufficient space for future development.

\section{Discussion}

We can now pay detailed attention to the concept or issues called Fourth Industrial Revolution. We will try to discuss the following statements:

1. The concept of the so-called Fourth Industrial Revolution is a manifestation of the inertial thinking in the historical turning point.

2. The concept of Fourth Industrial Revolution is too narrow and not comprehensive in macroeconomic sense. It covers main certain external phenomena, does not grab all the essential aspects of the present development and to some extent lacks proper equipment for doing it.

3. Much more substantial breakpoint is going on, which is comparable with the original industrial revolution as we know it from nineteenth century, but perhaps it is a much more pronounced change. Let us recall that the industrial revolution gave birth to the industry as a very new phenomenon, quite radically transform the whole society in dramatic and sometimes drastic social upheaval, when the old schemes were trying to defend their privileges against the new, incoming ones.

4. We should not be talking about upgrading the old economic base, but the birth of a new economic base of society. That happens outside the industry, as the industry was born outside the agriculture.

5. At the theoretical core and main pitfalls of understanding of what is going on with all the "maintainers of the inertia of thinking" is the question of the role of free (leisure) time, which directly relates to understanding, what are the human capabilities. It seems trivial, but it is not - whoever has acquired habits rather than actual abilities, hardly understands what the real human abilities are.

6. As a consequence of its essential "structural" deficiencies could the concept of Fourth Industrial Revolution be diverted to hiding the real problems and their causes, ideological sterilizing political forces and organizations, to increase the degree of people's confusion. 
For sure statically taken, a threat that poses the Fourth Industrial Revolution or simple Industry 4.0 concept to the national economy is significant. Without adaptive processes going on, it can lead to the hardly manageable consequences like higher structural unemployment, the issues of "useless" people who cannot get appropriate job despite they want to work and problems with social insurance schemes that count on common concepts of job market, as we know them now.

Let us work with the passage, where one of the theorists of Fourth Industrial Revolution P. Mason tries referring to Marx to justify the theoretical foundations of this concept:

"In the "Fragment on Machines" that he wrote in 1858 Marx imagines an economy in which the main role of machines is to produce, and the main role of people is to supervise them. He was clear that, in such an economy, the main productive force would be information. The productive power of such machines as the automated cotton-spinning machine, the telegraph and the steam locomotive did not depend on the amount of labour it took to produce them but on the state of social knowledge. Organisation and knowledge, in other words, made a bigger contribution to productive power than the work of making and running the machines.

Given what Marxism was to become - a theory of exploitation based on the theft of labour time - this is a revolutionary statement. It suggests that, once knowledge becomes a productive force in its own right, outweighing the actual labour spent creating a machine, the big question becomes not one of "wages versus profits" but who controls what Marx called the "power of knowledge".

In an economy where machines do most of the work, the nature of the knowledge locked inside the machines must, he writes, be "social". In a final late-night thought experiment, Marx imagined the end point of this trajectory: the creation of an "ideal machine", which lasts forever and costs nothing. A machine that could be built for nothing would, he said, add no value at all to the production process and rapidly, over several accounting periods, reduce the price, profit and labour costs of everything else it touched.

Once you understand that information is physical, and that software is a machine, and that storage, bandwidth and processing power are collapsing in price at exponential rates, the value of Marx's thinking becomes clear. We are surrounded by machines that cost nothing and could, if we wanted them to, last forever.

In these musings, not published until the mid-20th century, Marx imagined information coming to be stored and shared in something called a "general intellect" - which was the mind of everybody on Earth connected by social knowledge, in which every upgrade benefits everybody. In short, he had imagined something close to the information economy in which we live. And, he wrote, its existence would "blow capitalism sky high". (Mason, 2015)

The cited passage contains the fundamental problem of approach, which the concept of the Fourth Industrial Revolution is based on. What is the difference between what writes Marx, and how P. Mason interprets him? K. Marx emphasizes the expression of what form real human abilities have and what it means - the development of human capabilities. A person's ability to perform a "general labour", i.e. mediate and arrange together and conditionally interconnect processes within the area of his scope of authority. This specifically human capability can freely and almost infinitely develop, because it directly links to the development of scientific knowledge. A scientific knowledge is a process that also runs almost indefinitely. Therefore saving working time means an increase in available time "for the full development of the individual, which in turn acts back on the productive power of labour as the greatest productive power" (Marx, 1974, p. 343). Here is the basis of much higher levels of the new economy. 
Economy that will evolve significantly beyond the industry. The industry will absorb the results of this economy, just as agriculture had absorbed the results of the industry. On that basis, then the industry will develop with accelerating dynamics, as had once accelerated the pace of development of agriculture.

The main difference is that according to the vision of the Fourth Industrial Revolution the volume of labour is going to decrease, while according to Marx (and later to Richta, Kůs and ours) approach there will be plenty of labour available. Obviously, general labour. And so that productive services related to the acquisition, preservation and utilization of human capital could elevate every man (or at least most people) to the level of ability to perform general labour, you will need a lot of general labour in the area of productive services. The text interpreting Marx sees what is going on today very superficially. Therefore, it says that "the end of capitalism" in fact is to some extent already going on, through the natural technological evolution, the transition to the information society, the Fourth Industrial Revolution.

Marx's text very specifically shows the unlimited possibilities of human abilities, which is based on the ability to perform "general labour", i.e. the ability to arrange and mediate, put into mutual conditionality natural (and social) processes based on knowledge and understanding of its laws. Under certain social conditions is saving work time of the type of labour that takes the form of a trained workforce, the way to make a person could freely develop their ability to general labour, which in turn acts on the economy as the most productive forces. What kind of social conditions is it? The conditions in which the free development of each person is the condition for the free development of every other person, mutually supporting free development of individuals.

To do this, we still have a long way ahead. One of the main problems of social relationships (which still prevent the efficient functioning of the economy in the sense Marx anticipated the possibility to convert the savings of working time - meaning "old type of work" - the development of the ability of a person as a basis for general work - "a new type of work" - which becomes the most productive force) is investing in social position. The purpose of this investment is to reduce the possibility of the use of investment opportunities, which have other businesses and thus increase revenue from its own investment opportunities. To this issue we pay particular attention.

The concept of the Fourth Industrial Revolution sees primarily that information technologies allow substantial (indeed radical) increase labour substitution by technologies, i.e. to replace work and create free time (leisure). Nevertheless, systemically fails in the following:

- The understanding of the content of what distinguishes the (old) forms of work that can be replaced by the (new) forms of work that are irreplaceable, which are specifically human.

- In answer to the question of in what form can specifically human, irreplaceable forms of work (what Marx called the general labour) to develop, what role in it plays the leisure time, how the free time acts back on the economy as the most productive force.

- In identifying the barriers that in the current state prevent the use of convertible free time (time for full, free development of skills) in a most productive factor of economic growth.

Let us try most clearly and comprehensibly express what is currently going on. To do this, we use the term "investment opportunities" interpreted in the area of development of human capabilities.

Below investment opportunities we see entities, where you can invest (not necessarily just financial resources can be e.g. as well as opportunity costs, i.e. free time etc.) and what has some revenue (future income in cash and non-cash form). 
A man is born with some natural given dispositions and prerequisites, respectively. Prerequisites that can be or need not to be utilized. Since its birth a man offers through his existence certain investment opportunities (for investors of various kinds - family members, the state, and later others) associated with the development of his abilities. Specifically the development, preservation and application of his abilities.

In a society in which it would be created equal opportunities for the free development of each individual would be investment opportunities, which each of us possesses, used independently of external constraints which may be an asset position, integration into social structures (which can a man momentarily favour or vice versa discriminate) etc.

The society will never be perfect in the above sense. However, it may be imperfect only in the sense of partial imperfections, but also systemic imperfections, where some part of society discriminates against another part of the society in order to restrict the use of investment opportunities associated with the development (preservation and application) of their abilities, which in turn act as the most productive force in society.

The concept of the Fourth Industrial Revolution conceals the essence of what is going on, especially in the following points.

Unintentionally, but perhaps even deliberately ignores the current occurrence of investment in position rather than in human capital, its fatal effect on the conversion of free time in the most productive force, and then subsequently implications for growth, the economic role of productive services associated with the development, preservation and utilization of human abilities.

It offers a vision of "a slight improvement" of society with technologies that spare work without answering the question of what to do with your free time generated this way, thereby obscures the fact that the society is ahead of much deeper transformation.

It follows the inertial vision of reality at a historical turning point. I.e. at a time when we do not see some next phase of the industrial revolution, but a change in its scope, distinctiveness, depth and complexity comparable to the industrial revolution as such. The change, which created an entirely new economic sector. Just as historically from the crafts, the industry was born, then today the services related to the care for the person's abilities can give birth to a new sector of productive services directly focused on the acquisition, preservation and utilization of human capabilities, which will become the foundation of the new economy. The economy, in which man will be fully engaged in technologically "irreplaceable" forms of (general) labour, when we will achieve the point of overcoming the historical division between work and free time.

\section{Conclusions}

Economic growth can be dynamic yet sustainable. To achieve this, however, its character needs to change, thus significantly increasing the role of those industries that support the development of the ability to perform creative work, the ability to participate in innovation. Economy with high intensity of innovation tends to create whatever is required to meet the needs of people and further develop their ability to create nearly anything from almost nothing.

Both theoretical and practical refinement of the possibility of growth based on the dominant role of productive services' sector is essential. This can happen gradually, so that economy and people can adapt to new conditions and utilize the human potential that left from industrial sector, similarly to the process that happened in nineteenth century when people have been 
pushed out of rural agriculture with new opportunities in cities and factories. This is not to say that this process is miraculous and the pressure on effectiveness has to have its limits, but to vast extent it can be, when managed properly, actually beneficial for economy, if we find new interesting jobs that are irreplaceable with technology or just assisted by technology.

The concept of the Fourth Industrial Revolution is significant in terms of changes in the number of traditional mechanisms of production and the nature of employment. According to our analysis, however, it has much broader causes and consequences, than what is presented in relation to the functioning of the economy and the need to adapt especially in industrial sector.

In the short term within the framework of the concept of Fourth Industrial Revolution, which is understood too narrowly and at some levels it can lead to deduction of dangerous conclusions. This concept is the result of the inertial thinking in historical turning point. It notices that a certain type of human performances is being replaced by (information) technology, but does not operate with the notion that where there is demand for creative (general) work. The danger of such vision lies in the fact that it can lead to (ultimately even real) conclusions of redundancy, uselessness and futility of large social groups.

In the long term, there is a danger that in the society the games will be played based on the growing social differentiation and social exclusion of large social groups. Unless the socioeconomic system is designed to provide equality of (starting) opportunity for every citizen, changes in the nature of production and employment could trigger the centrifugal effect (Myrdal, 1968), i.e. further increasing wealth of the rich and the impoverishment of the poor. This limits the participation of wider social groups on economic development, which hardly compensates for a solution using purely solidarity-based social policy instruments, such as the basic income, which are not applicable at current economic reality. That is why the focus should be on prevention of these games' playing.

Overall, it is clear that the adaptation to the concept of the Fourth Industrial Revolution is not automatic and requires systematic preparation of infrastructure and socioeconomic systems that will allow and encourage wider involvement of the population in economic activities in the new conditions. Without these adjustments, the fulfilment of the pessimistic vision relating to employment, structural crisis and socioeconomic turbulences is real. At the same time, however, one can imagine a positive vision of exploiting the possibilities that are in the stage of development of civilization (which was partially anticipated by theorists) offer. It is significant to promote the inclusive nature of changes by focusing on equality of opportunity (chance), otherwise there is a risk of deepening the social differentiation and loss of important functions of large social systems (health, education, social security). Without a certain degree of social cohesion, they can fail to provide the expected functionality, regardless the quality of their construction and the solidarity/equivalency ratio.

\section{Acknowledgements}

The article was supported by the project SVV UFA No. 327 Financing of the branch of productive services and the Institutional support for long-term strategic development of research organization UFA in 2016. 


\section{Bibliography}

Bourdieu, P., 1986. The Forms of Capital. In: J. Richardson, Handbook of Theory and Research for the Sociology of Education (pp. 241-258). New York: Greenwood.

Credit Suisse, 2015. The Global Wealth Report 2015. Zurich: Credit Suisse.

Čadil, J. (2010). Regionální ekonomie: teorie a aplikace. Praha: C.H.Beck.

Hujo, K. (2014). Reforming Pensions in Developing and Transition Countries. New York: United Nations.

IMF, 2015. Causes and Consequences of Income Inequality: A Global Perspective. IMF.

Klusoň, V., 2005. O ekonomické odpovědnosti. Politická ekonomie. 2005., Vol. 52, No. 4. pp. 436-458.

Korbel. P., 2015. Průmyslová revoluce 4.0: Za 10 let se továrny budou řídit samy a produktivita vzroste o třetinu. Hospodářské noviny. 17.5.2015. Available from: http://byznys.ihned.cz/c1-64009970prumyslova-revoluce-4-0-za-10-let-se-tovarny-budou-ridit-samy-a-produktivita-vzroste-otretinu.

Krebs, V., et al., 2015. Sociální politika. $6^{\text {th }}$ ed. Praha: Wolters Kluwer.

Kůs, J., 2015. Lidská práce možná nebude důležitá. OSEL - Open Source E-learning. 23.09.2015. Available from: http://www.osel.cz/8446-lidska-prace-mozna-nebude-dulezita.html.

Marx, K., 1974. Rukopisy „Grundrisse“ II. Praha: Svoboda.

Mason, P., 2015. PostCapitalism. A Guide to Our Future. Allen Lane. ISBN: 978-18-4614-738-8.

Mlčoch, P., 2007. Ekonomie a štěstí: Proč více někdy není lépe. Politická ekonomie. 2007., Vol. 54, No. 2. pp. 147-163.

Myrdal, G., 1968. Asian Drama: An Inquiry into the Poverty of Nations. New York: Twentieth Century Fund.

Richta, R. et al., 1966. Civilizace na rozcestí. Praha: Svoboda, $236+20$ p.

Štika, P., 2009. Ekonomie štěstí. Politická ekonomie. 2009., Vol. 56, No. 2. pp. 250-262.

Valenčík, R., et al., 2014. Perspektivy a financování odvětví produktivních služeb. Praha: VŠFS-EUPRESS. ISBN 978-80-7408-103-3. Available from: http://www.vsfs.cz/prilohy/konference/lk 2015 perspektivy.pdf

Valenčík, R., et al., 2015. Čtvrtá průmyslová revoluce, nebo ekonomika produktivních služeb? Praha: VŠFS-EUPRESS. ISBN 978-80-7408-126-2.

Vostatek, J., et al., 2013. Financování a nákladovost sociálních služeb. Tábor: Asociace poskytovatelů sociálních služeb ČR, o.s..

Jan Mertl_jan.mertl@outlook.com

Radim Valenčík valencik@seznam.cz

University of Finance and Administration

Estonská 500, 10100 Praha 10

Czech Republic 